\title{
Balkan Journal of Wildlife Research
}

\section{REVIEW OF GENETIC MONITORING PROGRAMS OF WILDLIFE SPECIES IN SERBIA}

\author{
Ivana Matić $^{1{ }^{* * *}}$, Iva Gorše $^{1 * *}$, Milomir Stefanović ${ }^{1}$, Mihajla Djan $^{1}$, Nevena Veličković ${ }^{1}$
}

Summary: Genetic monitoring, as one of the main aspects in long-term population monitoring, has an important role in establishing an effective management strategy and biological conservation of wildlife. Determination and monitoring of genetic variability as well as identification of management units represent the best methods of estimating the natural population potential for adaptation and survival. Here we present a comparative overview of data obtained through genetic monitoring of three wildlife species in Serbia brown hare, wild boar, and grey wolf. The overall genetic monitoring of brown hare, wild boar and grey wolf have been conducted for a period of twenty, ten and five years, respectively. The first determination of genetic variability in brown hares from Serbia, which was based on the analysis of microsatellite polymorphism, suggested an optimal three-year monitoring period for this species while continual genetic monitoring has revealed maintenance of moderate genetic diversity over twenty years. Furthermore, it is suggested that future genetic monitoring should include more informative molecular markers, such as those linked to adaptive traits. Microsatellite molecular markers have provided much of the required information about the wild boar population. The wild boar is one of the most important game species, thus it is crucial to estimate adequate management measures in order to preserve its genetic variability, but also to prevent the possible territorial expansion of the species. The panel of 18 autosomal microsatellite loci proved to be very informative for the grey wolf population. The Serbian wolf population is relatively stable for now, but it is very important to maintain appropriate genetic monitoring to preserve this valuable reservoir of genetic variability. The results, obtained through genetic monitoring of these three species in Serbia, support integration of genetic information with the traditional methods for hunting management strategy in order to provide a long-term sustainability.

Keywords: brown hare; genetic monitoring; grey wolf; wild boar

\section{Introduction}

Continual population monitoring is crucial for creating an effective management strategy and for biological conservation of wildlife (Nichols \& Williams, 2006). This is important for game species, due to their biological and economical value, as well as for species of specific conservation interest. One of the main aspects of continual monitoring of wildlife populations is genetic monitoring. This approach is using predefined molecular markers and standardized protocols with the aim to assess the level of genetic variability within populations, the genetic structure of populations, level of inbreeding and other data of practical interest (Hedrick \& Kalinowski, 2000; Palsbøll et al., 2007; Schwartz et al., 2007; Laikre, 2010). The parameters describing genetic variability in time scale are essential for monitoring changes in the population potential for survival and adaptation, as well as for detecting possible events in population include hybridization, introgression and fragmentation. Moreover, continual population monitoring provides crutial information for establishing management plan for an adequate population response to negative effects, such as overhunting and/or unsuitable ecological management measures (Harris et al., 2002; Allendorf et al., 2008; Laikre et al., 2008). In regard to this, the determination of appropriate molecular markers is necessary.

\footnotetext{
${ }^{1}$ Ivana Matić, PhD Student, research trainee; Iva Gorše, PhD Student, research trainee; Milomir Stefanović, PhD, Assistant; Mihajla Djan, PhD; Full Professor, Nevena Veličković, PhD Associate Professor, Department of Biology and Ecology, Faculty of Sciences, University of Novi Sad, Trg D. Obradovica 3, 21000 Novi Sad, Serbia

Correspondence author's name, address and e-mail: Ivana Matić, ivanam@dbe.uns.ac.rs; Iva Gorše, iva.gorse@dbe.uns.ac.rs

** Both authors contributed equally to this manuscript
} 
Genetic monitoring and identification of management units through usage of molecular markers represent the best methods for estimating the natural population potential for survival and adaptation (Schwartz et al., 2007). Since a population growth does not actually reflect good fitness of a population, it is indispensable from the conservation biology to define all present molecular variants in the population. The disappearance of certain genes significantly reduces genetic variability in long-term, as well as the chance of adaptations to environmental changes. Therefore, the significant increase of homozygosity in large population may results in drastic changes caused by negative anthropogenic or any other effects, to the same degree as in small populations. Accordingly, regardless of the population size, there is a necessity for the determination and monitoring of genetic variability as the basis for establishing effective management measures and biological conservation. Furthermore, a population's genetic structure has a great role in long-term survival ability, thus precise knowledge of population structure allows a management plan design for a particular population (Hedrick, 2001; Higgins \& Lynch, 2001; Manel et al., 2003; Hampton et al., 2004; Palsbøll et al., 2007; Avise, 2008).

Considering all the available data, continual genetic monitoring, as an essential approach for evaluating and improving management strategy, should be applied into practice in order to provide long-term sustainability of the wildlife populations. Here, we aimed to present an overview of data obtained through genetic monitoring of three species in Serbia - brown hare, wild boar, and grey wolf.

The genetic monitoring of brown hare (Lepus europaeus) from Serbia

The brown hare (Lepus europaeus, Pallas 1778) represents one of the most important and hunted game species in Europe, occupying open woodland and grassland up to $1500 \mathrm{~m}$. It is the only Lepus species that can be found in Serbia and the Balkan Peninsula (Suchentrunk et al., 2000; Mammuris et al., 2001; Kasapidis et al., 2005; Stamatis et al., 2009). The adaptation of this species to the agricultural landscape has resulted in its spread through farmland all over its range, especially in the northern province of Serbia, Vojvodina, the territory with the largest number of hunting sites of all areas in Serbia. The brown hare has been characterized as the keystone prey species in agro-ecosystems, contributing to the flow of organic matter and nutrients. Moreover, it is a species of high economical value due to the significant role in the hunting economy (Vapa et al., 2007). Since the 1960s, a strong decline of brown hare populations was detected in the whole of Europe, including Serbia, mainly as a consequence of anthropogenic activities and environmental changes (Fickel et al., 2005; Vapa et al., 2007). Changes in farming methods, which are represented by agricultural intensification and mechanization, together with the homogenization of crop structure and intensive pesticide usage, reduced the area of hares' natural habitat, affecting the availability of high-quality diet for it (Beuković et al., 2012; Smith et al., 2015). Therefore, anthropogenic impact on habitat, as well as overhunting and the appearance of various diseases are recognized as the main reasons of the remarkable decline of brown hare populations (Vapa et al., 2007; Djan et al., 2013a). Consequences, visible in the decreasing of genetic variability and high inbreeding rates due to reduced gene flow, are impairing the potential of the population for long-term survival and adaptation.

Different classes of molecular markers were used in the assessment of brown hare genetic diversity in Serbia, along with the development of technology. The first genetic analyses for the species in Serbia were done for population from Vojvodina, using allozymes (Vapa et al., 1999; Vapa et al., 2002; Davidović, 2003). These analyses revealed low gene pool divergence among local populations in Vojvodina Province and low level of structuring, defined by the Danube river as a main geographical barrier to gene flow at local scale. Due to disadvantages of allozyme markers, represented by low informativeness and technical limitations (Schlötterer, 2004), these markers were discarded as markers of choice in a continual monitoring of brown hare populations in Serbia. Djan et al. (2006) analyzed polymorphism of three mtDNA regions: cytochrome oxidase I (COI), Control region, and 12S/16S rRNA, by the mtDNA RFLP-PCR method, in the L. europaeus population from Vojvodina province. Haplotype diversity value obtained through this study was at the level for Central European brown hares (Hartl et al., 1993). The presence of haplotypes characteristic for Central European brown hares was observed in population from Vojvodina, indicated that brown hares from Vojvodina belong to the Central European group. Furthermore, this study supported that Danube river causes a low level of structuring in brown hare population from Vojvodina. It seems that large rivers might have some influence on gene flow and presence of the large river stream might limit, but cannot stop, the gene 
flow between regions. However, for the same reason as allozymes, mtDNA RFLP-PCR method were discarded for use in a continual monitoring of brown hare populations in Serbia. Thus, microsatellites and mtDNA sequence, as more appropriate genetic markers, were employed in the further brown hare population genetic studies (Djan et al., 2006; Djan, 2008; Djan et al., 2013b; Stefanović et al., 2018).

Markers of choice in population genetic studies of the brown hare are usually microsatellite loci developed and discovered in Oryctolagus cuniculus (Mougel et al., 1997; Surridge et al., 1997). Assessment of the genetic diversity and structure in brown hares from Serbia is based on microsatellites, which were previously proved to be informative: Sat2, Sat5, Sat12 (Mougel et al., 1997), Soll33 (Surridge et al., 1997), Lsa2 and Lsa3 (Kryger et al., 2002).

The first genetic analysis of brown hare populations from Serbia using microsatellites was done by Djan (2008) and one of the recommendations for the management of L. europaeus in Serbia, after this research, was a determination of genetic variability in a defined period of three years. This study revealed a high degree of gene flow and low genetic differentiation at the local level, with only certain geographical barriers affecting the level of gene flow and hence causing structuring into genetically differentiated subunits (i.e., subpopulations). Medium level of genetic polymorphism was detected in brown hares from Serbia, as expected for large continuously dispersed populations of mammals (Suchentruk et al., 2003). Moreover, using different statistical approaches, Djan et al. (2015), through the analysis of six microsatellite loci (Sat2, Sat5. Sat12, Sol33, Lsa2 and Lsa3), detected the structuring of the brown hare population from Serbia into two defined subpopulations: Northern-Central-Eastern (NCE) and Northern-Western (NW) Serbia. Higher values of genetic diversity parameters were found in the NCE subpopulation, which includes individuals from Vojvodina, Northern-Central Serbia, and Northern-Eastern Serbia, compared to the NW subpopulation comprised of hares from Northern-Western Serbia. Therefore, these subpopulations have been considered as separate management units. It was recommended to prevent human mediated admixtures between defined subpopulations, in order to preserve existing genetic diversity and to avoid further reduction of genetic variability in NW Serbian subpopulation. It is possible that the population structure of L. europaeus in Serbia actually represents a phylogeographic signal from the past, which was created under the strong influence of the climatic oscillations during the Late Quaternary (Djan et al., 2017). Similar pattern of the brown hare population structure in Serbia was observed from the earlier studies of genetic variability in brown hares from Vojvodina, which have indicated a low level of differentiation within this northern province rich in hunting grounds (Djan, 2008; Djan et al., 2013a) and afterwards confirmed with the recent studies (Stefanović et al., 2018; Gorše et al., 2019). Although the results revealed a moderate genetic diversity and the existence of gene flow in Vojvodina, the presence of local fixation of certain alleles was also observed. Therefore, Stefanović et al. (2018) proposed particular attention in further monitoring of hares from hunting grounds "Srem" and "Varoški rit", in order to avoid possible interruptions in gene flow as well as further genetic isolation. The results of continual genetic monitoring, obtained using different molecular markers, show the maintenance of a moderate genetic diversity over a twenty-year period (Table 1).

Table 1. The time scale of genetic variability of brown hares from the territory of Serbia and/or Vojvodina obtained through the analysis of different molecular markers (for microsatellites the number of analyzed loci is given in brackets). The arrow represents the time scale from the beginning of the studies via molecular markers; years below it refer to the hunting season, while above the arrow are presented references of the studies themselves. Note that the primacy in the time scale is given to the hunting year in relation of the reference, because it provides more reliable information about changes in genetic diversity over the time. 


\begin{tabular}{|c|c|c|c|c|c|c|c|c|}
\hline Ho-He/Hd & $0.145-\mathrm{N}$ & $\begin{array}{l}0.07- \\
0.075\end{array}$ & $\begin{array}{c}0.056- \\
0.067\end{array}$ & 0.34 & 0.876 & 0.916 & $0.450-0.653$ & $0.539-0.785$ \\
\hline Marker & allozymes & allozymes & allozymes & $\begin{array}{l}\text { mtDNA } \\
\text { (RFLP) }\end{array}$ & \multicolumn{2}{|c|}{ mtDNA } & \multicolumn{2}{|c|}{ microsatellites (6) } \\
\hline $\mathrm{n}$ & $\mathrm{N}$ & 26 & 77 & 77 & 38 & 54 & 79 & 78 \\
\hline \multirow[t]{3}{*}{ Region } & Vojvodina & Vojvodina & Vojvodina & Vojvodina & Central Serbia & Vojvodina & $\begin{array}{c}\text { Central } \\
\text { Serbia }\end{array}$ & Vojvodina \\
\hline & $\begin{array}{c}\text { Vapa et } \\
\text { al., } 1999\end{array}$ & $\begin{array}{c}\text { Vapa et } \\
\text { al., } 2002\end{array}$ & $\begin{array}{c}\text { Davidović, } \\
2003\end{array}$ & $\begin{array}{c}\text { Djan et } \\
\text { al., } 2006\end{array}$ & \multicolumn{4}{|c|}{$\begin{array}{l}\text { Djan, } \\
2008\end{array}$} \\
\hline & 1998 & 1999 & $2001-2003$ & $\begin{array}{l}2001- \\
2003\end{array}$ & \multicolumn{4}{|c|}{ 2003-2006 } \\
\hline
\end{tabular}

\begin{tabular}{|c|c|c|c|c|c|}
\hline Ho-He/Hd & $0.825-0.879$ & 0.977 & 0.938 & $0.516-0.7$ & $0.499-0.707$ \\
\hline Marker & microsatellites (3) & mtDNA & mtDNA & microsatellites (6) & microsatellites (6) \\
\hline $\mathrm{n}$ & 60 & 39 & 90 & 23 & 89 \\
\hline Region & Vojvodina & Central Serbia & Vojvodina & Central Serbia & Vojvodina \\
\hline & $\begin{array}{c}\text { Djan et al., } \\
2013 \mathrm{a}\end{array}$ & $\begin{array}{c}\text { Stefanović et al., } \\
2016\end{array}$ & $\begin{array}{c}\text { Djan et al., } \\
2013 \mathrm{~b}\end{array}$ & $\begin{array}{c}\text { Matić et al., } \\
2019\end{array}$ & $\begin{array}{c}\text { Gorše et al., } \\
2019\end{array}$ \\
\hline & $2007-2009$ & 2010 & 2012 & 2018 & 2018 \\
\hline
\end{tabular}

Ho - observed heterozygosity; $\mathrm{He}$ - expected heterozygosity; $\mathrm{Hd}$ - haplotype diversity; $\mathrm{N}$ - unknown data.

The time scale reveals a pattern of the moderate increases in heterozygosity over time observed through the analysis based on two molecular markers - microsatellites and mtDNA control region sequences (Table 1). This shows the importance in the integration of genetic information with the traditional methods for planning the brown hare hunting management strategy as well as with prior management measures such as reduction of hunting season period, in order to provide long-term sustainability of this species in Serbia.

The sudden heterozygosity increase detected in the period from 2007 to 2009 in brown hares from Vojvodina (Table 1), could be due to the usage of three microsatellite loci, which previously proved to be high polymorphic. All other studies of brown hare' genetic diversity, which are presented in the time scale, employed additional but less polymorphic loci, in order to obtain diversity through analysis of microsatellite markers with varying levels of polymorphism.

Observed and expected heterozygosity values, which were detected during period of monitoring are in range with the values detected for Central European hare populations (Fickel et al., 2005; Ben Slimen et al., 2008). However, values of expected heterozygosity were higher than the observed, which could be caused by the inbreeding effect due to the small number of individuals involved in reproduction or by the fact that mating was occurring among the closely related individuals. Although obtained results indicated moderate genetic diversity, particular attention should certainly be oriented toward further possible changes in the level of genetic diversity. Further genetic monitoring should encompass broader sampling and more informative markers, such as those linked to adaptive traits.

The genetic monitoring of wild boar (Sus scrofa) from Serbia

The wild boar (Sus scrofa Linnaeus, 1758 ) is one of the most important game species and also one of the most widespread terrestrial mammals. Characterized by great ecological adaptability and opportunistic 
nutrition, this species has the ability for a rapid recolonization (Alexandri et al., 2012; Veličković et al., 2015). Wild boars, as is the case with other large mammals, have also faced with Quaternary climate oscillations, especially during the last glacial period, with the major changes in the geographical range of European wild boar populations. Given that the three European peninsulas (Balkan, Iberian and Apennine) provided refuge for many animal and plant species during the ice ages (Taberlet et al., 1998; Hewitt, 2000), wild boar survived only in these regions. Considering their great ecological adaptability, it is assumed that wild boars have recolonized Europe from these regions. This species is native to Serbia and has represented one of the most popular game species, making it important in ecological as well as in an economical sense. Due to significant increases in agriculture and unregulated hunting at the end of 19th and beginning of the 20th century, there was a strong demographic decline and regional extinctions occurred in the wild boar populations in Europe. Also, following the habitat destruction and decline in food availability due to human influence, their numbers have dwindled (Apollonio et al., 2010). After the Second World War, their population numbers have increased in some European countries (Sez-Rozuela \& Tellera 1986). Increase in wild boar population size continued and has been particularly significant in the last fourteen years due to high reproductive rate, climate change, ability to rapidly recolonize, feeding, decreased hunting across Europe and lack of predatory species (Saez-Royuela \& Telleria, 1986; Apollonio et al., 2010; Scandura et al., 2011). During the expansion in the population density of the wild boar, there was an increase in conflict with humans in certain areas, which resulted in this species being viewed as a pest (Frank et al., 2015). Furthermore, it is important to prevent the expansion of African swine fever (ASF), which is considered to be one of the most devastating diseases of the wild boar and domestic pig (De la Torre et al., 2013). Therefore, appropriate strategies for wild boar populations' preservation have become necessary. It remains to be determined whether high population density also provides high genetic diversity.

The first characterizations of the wild boar in Serbia were based on microsatellite analysis from the hunting area in Vojvodina province, near Danube river (Veličković, 2008; Djan et al., 2008; Veličković et al., 2008). This was also the first instance of successful amplification and usage of loci SW251 (Rohrer et al., 1994) and SW2429 (Alexander et al., 1996) in wild boar. Obtained results showed a moderate level of polymorphism within the wild boar population from Danube area. Subsequent research of wild boar population from the Podunavlje-Podravlje hunting area, which includes five microsatellite loci (S0068 and S0005 (Fredholm et al. 1993), SW251 and SW857 (Rohrer et al., 1994) and SW2429 (Alexander et al., 1996)) showed a high level of genetic diversity within the analyzed population. This report provides a starting point in genetic characterization of wild boar population in the western part of the Balkans and an important step towards the development of conservation and management plan for this species in the Balkan region (Veličković et al., 2010). Similar results were obtained in the wild boar population from Vojvodina, where the before mentioned five loci were also included (Djan et al., 2012).

In a short communication, Veličković et al. (2012) investigated the genetic structure of a wild boar population in the West Balkan among three regions, Vojvodina, Slavonia and Bosnia. Four microsatellite loci (S0068, S0005, SW251, SW2429), previously proven to be polymorphic in the wild boar population, were used in the analysis. Results have indicated the presence of a spatial structuring with the presence of two genetic clusters, northern which includes population from Vojvodina and Croatia and southern which includes wild boars from Bosnia. Such division can be explained by differences in habitat, where Vojvodina and Slavonia are mostly lowland regions, while hilly areas are primarily present in Bosnia. Also, Sava River may represent a geographical barrier to gene flow between these populations (Veličković, 2014). Increasing the number of used loci was suggested by the author in order to obtain a definitive conclusion regarding the nuclear gene pool variability of the wild boar population from the West Balkan region.

First analysis of mitochondrial DNA (mtDNA) variation in wild boar in Serbia, including individuals from the northern Dinaric Balkans, was done by Veličković et al. (2015). A fragment of the mtDNA control region (443 bp) was sequenced and has shown relatively high genetic variability. This phylogeographical analysis provides new information regarding a large and previously unsampled region of the Balkans. The research of the European wild boar population has demonstrated that recent gene pool primarily originate from ancient genetic diversity generated by processes active during the last glaciation, which also supports the premise of the Balkans role as a genetic reservoir of European wild boar. 
Next research of the wild boar from Balkan included 11 tetranucleotide microsatellites loci (Biotype AG, Dresden, Germany) (Veličković et al., 2016). Obtained results showed a strong population structuring in the wild boar population in Europe into 14 subpopulations. Also, 3 gene pools from Europe were observed with genetic differentiation among the three peninsulas, Balkan, Iberian and Apennine, while wild boar from Central-eastern Europe showed the admixture of the three gene pools. These observations were consistent with those made in previous studies (Alexandri et al., 2012; Veličković et al., 2016), which assumed that all three southern European refugiums could have had a role in the postglacial recolonization of the wild boar population in Europe. Recent population bottlenecks were reported and are probably related to human influence during the last several decades. Following the time scales (Table 2), it can be concluded that the application of nuclear markers has proven to be useful in the genetic monitoring of wild boar populations, conducted for the duration of ten years. Moreover, an increase in the number of analyzed microsatellite loci provides a much better insight into genetic diversity of the population in question.

Table 2. The time scale of genetic variability of wild boar from the territory of Serbia (West Serbia, South Serbia, East Serbia, Peri-Dinaric, South Pannonian, South Central Balkans and South Pannonia region) obtained through the analysis of different molecular markers (for microsatellites the number of analyzed loci is given in brackets). The arrow represents the time scale from the beginning of the studies via molecular markers; years below it refer to the hunting season, while above the arrow are presented references of the studies themselves. Note that the primacy in the time scale is given to the hunting year in relation of the reference, because it provides more reliable information about changes in genetic diversity over the time.

\begin{tabular}{|c|c|c|c|c|}
\hline Ho - He / Hd & $0.514-0.776$ & $0.579-0.853$ & $\begin{array}{c}0.60-0.85 \\
\text { (Vojvodina: } 0.58-0.8 \text { ) }\end{array}$ & $0.69-0.77$ \\
\hline Marker & microsatellite (4) & microsatellite (5) & microsatellite (4) & microsatellite (11) \\
\hline $\mathrm{n}$ & 51 & 51 & 134 & 62 \\
\hline \multirow[t]{3}{*}{ Region } & Vojvodina & $\begin{array}{l}\text { Podunavlje- } \\
\text { Podravlje }\end{array}$ & $\begin{array}{l}\text { West Balkan Region } \\
\text { (Vojvodina, Slavonia } \\
\text { and Bosnia) }\end{array}$ & Vojvodina \\
\hline & Veličković et al. 2008 & $\begin{array}{l}\text { Veličković et al. } \\
2010\end{array}$ & Veličković et al. 2012 & Veličković et al. 2013 \\
\hline & 2008 & 2010 & 2012 & 2013 \\
\hline
\end{tabular}




\begin{tabular}{|c|c|c|c|c|}
\hline Ho - He / Hd & $\begin{array}{c}\text { WSER=0.333; ESER=0.284; } \\
\text { SSER=0.524 }\end{array}$ & $0.70-0.78$ & 0.502 & $0.740-0.780$ \\
\hline Marker & mtDNA & $\begin{array}{c}\text { mtDNA, } \\
\text { Microsatellite (11) }\end{array}$ & mtDNA & microsatellite (11) \\
\hline $\mathrm{n}$ & $\begin{array}{c}33 \text { (WSER=6; ESER=20; } \\
\text { SSER=7) }\end{array}$ & 98 & $\begin{array}{c}\text { Peri-Dinaric (20); } \\
\text { South Pannonian } \\
\text { (43) }\end{array}$ & $\begin{array}{c}\text { South Central Balkans } \\
\text { (33); South Pannonia (79) }\end{array}$ \\
\hline Region & $\begin{array}{c}\text { Serbia (West Serbia; East } \\
\text { Serbia; South Serbia) }\end{array}$ & Serbia & $\begin{array}{c}\text { Peri-Dinaric; South } \\
\text { Pannonian }\end{array}$ & $\begin{array}{c}\text { South Central Balkans; } \\
\text { South Pannonia }\end{array}$ \\
\hline & Djan et al. 2013 & Veličković 2014 & $\begin{array}{c}\text { Veličković et al. } \\
2015\end{array}$ & Veličković et al. 2016 \\
\hline & 2013 & 2014 & 2015 & 2016 \\
\hline
\end{tabular}

Ho - observed heterozygosity; He - expected heterozygosity; Hd - haplotype diversity; SSER - South Serbia; WSER - West Serbia; ESER - East Serbia.

Taking all of the available data into account, it can be concluded that Balkan represented one of the most important genetic reservoirs of the wild boar. Three refuges, Balkan, Iberian and Apennine peninsula have maintained the gene pool during the last glacial and have provided a starting point for the recolonization of the European regions. Wild boar also represents an important game species and is therefore of great economic importance. Consequently, the development of adequate management strategies is imperative in order to preserve the existing genetic diversity and prevent possible expansion of this species.

The genetic monitoring of grey wolf (Canis lupus) from Serbia

The grey wolf (Canis lupus, Linnaeus 1758), as a very mobile species, is characterized by a wide distribution. Historically, wolves were widespread in whole Europe, occurring at different habitats ranging from Arctic tundra to Arabian deserts (Randi, 2011). Accordingly, this species is characterized by significant phenotypic variations in external morphology, such as body size, fur color, weight and skull morphology (Milenković et al., 2010). The grey wolf is a major predator and plays a key role in establishing the structure and function of the ecosystem regulating predator-prey relationship (Randi, 2011). In the past, wolves had the largest habitat among all mammal species with ranges of distribution much larger than today. However, at the end of the 19th and the beginning of the 20th century, grey wolf populations decreased due to human induced habitat destruction and a decline in prey abundance, so the once large and continuous population became fragmented (Boitani, 2000). This phenomenon was especially present in the Western Europe wolf populations which faced a drastic decline during the last few centuries, probably because of the extensive human-caused contraction (Luccini, 2004). Population structure analyses using microsatellite genetic markers showed that European grey wolf metapopulation (Randi 2011) consists of 10 populations (Scandinavian, Karelian, Baltic, Central European Lowland, Italian peninsular, Alpine, Carpathian, Northwest Iberian, Sierra-Morena and Dinaric-Balkan population) (Šnjegota 2018). This structure is probably due to the fragmentation of the populations and the bottleneck that wolves experienced in Western Europe, as well as in Central Europe and Scandinavia (Hindrikson et al., 2016).

Since the 1990s, the scientific community showed a keen interest in studying the genetic diversity of wolves and the development of molecular methods brought a revolution in research of grey wolf population (Huang et al., 1997).

Wolves in Serbia belong to the large Dinaric-Balkan population, which represents the border between the Eastern and the Western European wolf populations (Djan et al. 2014). Legal status of the grey wolf in Serbia is controversial since it is listed as a game species by the Game and Hunting Law and is legally hunted throughout the year in most areas of the country. Hunting is strictly prohibited only in the province of Vojvodina, where wolves can rarely be found (Kaczensky et al., 2013). 
Some of the earliest studies of the grey wolf in Serbia, based on the morphology, propose that the DinaricBalkan wolf population is differentiated into eastern and western subpopulations along the Morava-Vardar valley (Milenković et al., 2007). In the research of Djan et al., (2014) population structure and phylogeography of the grey wolves from the Central Balkans was analyzed, using 192 mtDNA control region sequences, among which 87 were produced in this research. The authors analyzed mtDNA sequence variability of wolves from the Central Balkans, the population structure of the Dinaric Balkan population, the demographic history and phylogeographic position of Central Balkan wolves. Results have indicated the presence of two subpopulations within the Dinaric-Balkan wolf population, eastern and western, which were spatially divided along Drina river. This is the first reported study of the Serbian wolves' genetic diversity by applying mtDNA.

The first study of the Serbian wolves' genetic diversity using microsatellite loci,, was done by Bakan at al. (2014). The main aim of this research was to estimate the differentiation between grey wolves from two regions, the Balkans and Carpathians. The authors used a panel of 15 microsatellite loci designed by Francisco et al. (1996) and calculated the basic parameters of genetic variability for the total sample and three wolf populations separately, where wolves from Serbia showed the following mean results: Ho=0.526,

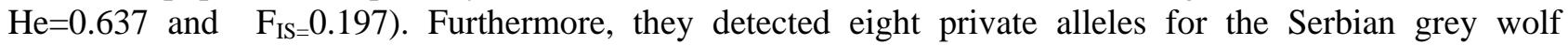
population. Bayesian cluster method, implemented in STRUCTURE 2.2 (Pritchard et al., 2000) confirmed that wolves from Serbia belong to the large Dinaric-Balkan population.

The next characterization of grey wolves from Serbia via microsatellites applied the panel of 18 loci, The Canine Genotypes ${ }^{\mathrm{TM}}$ Panel 1.1 kit (Finnzymes Diagnostics) (Djan et al., 2016). The results obtained in this research showed the higher mean values of heterozygosities $(\mathrm{Ho}=0.69 ; \mathrm{He} 0.75)$ and lower mean $\mathrm{F}_{\text {IS }}$ value (0.008) compared to the results from Bakan et al. (2014). Therefore, it can be concluded that a panel of 18 microsatellite loci is more informative than the previously used panel of 15 microsatellite loci (Table 3). Furthermore, subsequent research of the grey wolf from Serbia based on the same panel of 18 microsatellite loci also showed a significant level of genetic diversity and no population structure (Matić, 2017; Djan et al., 2018; Matić et. al., 2019) formed during the five years of genetic monitoring.

Table 3. The time scale of genetic variability of the grey wolf from the territory of Serbia obtained through the analysis of different molecular markers (for microsatellites the number of analyzed loci is given in brackets). The arrow represents the time scale from the beginning of the studies via molecular markers; years below it refer to the hunting season, while above the arrow are presented references of the studies themselves.

\begin{tabular}{|c|c|c|c|c|c|c|}
\hline Ho - He / Hd & 0.442 & $0.526-0.637$ & $0.69-0.75$ & $0.72-0.79$ & $0.713-0.783$ & $0.693-0.772$ \\
\hline Marker & mtDNA & $\begin{array}{c}\text { microsatellite } \\
\text { (15) }\end{array}$ & $\begin{array}{c}\text { microsatellite } \\
\text { (18) }\end{array}$ & $\begin{array}{c}\text { microsatellite } \\
\text { (18) }\end{array}$ & $\begin{array}{c}\text { microsatellite } \\
\text { (18) }\end{array}$ & $\begin{array}{c}\text { microsatellite } \\
\text { (18) }\end{array}$ \\
\hline $\mathrm{n}$ & 53 & 120 & 75 & 79 & 78 & 59 \\
\hline \multirow[t]{3}{*}{ Region } & Serbia & Serbia & Serbia & Serbia & Serbia & Serbia \\
\hline & $\begin{array}{c}\text { Djan et al. } \\
2014\end{array}$ & Bakan et al. 2014 & Djan et al. 2016 & Matić 2017 & $\begin{array}{c}\text { Djan et al. } \\
2018\end{array}$ & $\begin{array}{c}\text { Matić et al. } \\
2019\end{array}$ \\
\hline & 2014 & 2014 & 2016 & 2017 & 2018 & 2019 \\
\hline
\end{tabular}

Ho - observed heterozygosity; He - expected heterozygosity; Hd — haplotype diversity. 
One of the most important aspects in developing adequate management strategies for natural populations is the knowledge of genetic diversity and population structure (Zachos \& Hackländer, 2011). As was previously stated, wolves from the Balkans represent the remnants of a larger preglacial population and are, therefore, crucial for the conservation of genetic diversity. Although the wolf population in Serbia is currently stable (Djan et al. 2018), it is of great value to maintain genetic monitoring. Excessive human activity leads to the disappearance of rare alleles, which are important for the recolonization and recovery of grey wolf populations across Europe.

\section{Conclusion}

Genetic monitoring provides insight into genetic variability, as well as an estimation of population potential for adaptation and survival. In addition to the indisputable value of game population fitness in hunting, economy, gene pools of brown hare, wild boar and grey wolf populations from Serbia represent an important genetic resource for maintaining the sustainability of these species in the whole of Europe. The results, obtained through genetic monitoring of these three species in the territory of Serbia, have revealed the significant importance of this approach in establishing an adequate management strategy for wildlife populations. Therefore, genetic monitoring is crucial for maintaining biodiversity and preventing population expansion, as well as for adequate game species management during the hunting season, which has not only ecological but also economic significance. This approach, being essential for evaluating and improving management strategy, should be incorporated into standard practice in order to provide a basis for long-term sustainability of populations.

\section{References}

1. Alexander, L., J., Rohrer, G., A., C., W. Beattie (1996) Cloning and characterization of 414 polymorphic porcine microsatellites, Animal Genetics 27, pp. 137-148.

2. Alexandri, P., Triantafyllidis, A., Papakostas, S., Chatzinikos, E., Platis, P., Papageorgiou, N., Larson, G., Abatzopoulos, T., J., Triantaphyllidis, C. (2012) The Balkans and Colonization of Europe: The Post-Glacial Range Expansion of the Wild Boar, Sus scrofa, Journal of Biogeography 39, pp. 713-723.

3. Apollonio, M., Andersen, R., Putman, R. (2010) European Ungulates and Their Management in the 21st Century, Cambridge: Cambridge University Press.

4. Bakan, J., Lavadinović, V., Popović, Z., Paule, L., (2014) Genetic differentiation of grey wolf population (Canis lupus 1.) from Balkan and Carpathians, Balkan Journal of Wildlife Research, 1(1), pp. 87-93.

5. Beuković, M., Popović, Z., Đorđević, N (2012) The management analysis of hare populations in Vojvodina for the period 1997-2011, In International Symposium on Hunting Modern Aspects of Sustainable Management of Game Population, Zemun-Belgrade (Serbia), 22-24 June 2012, pp. 9-15.

6. Boitani, L. (2000) Action Plan for the conservation of the wolves (Canis lupus) in Europe. Convention on the Conservation of European Wildlife and Natural Habitats (Bern Convention). Nature and environment, No. 113. Council of Europe Publishing, Strasbourg.

7. Davidović M. (2003) Molekularno genetička analiza varijabilnosti populacije zeca (Lepus europaeus Pallas) u Vojvodini, Master thesis, Faculty of Biology, University of Belgrade, Serbia.

8. Djan, M., Maletić, V., Trbojević, I., Popović, D., Veličković, N., Burazerović, J., Ćirović, D. (2014) Genetic diversity and structuring of the grey wolf population from the Central Balkans based on mitochondrial DNA variation, Mammalian Biology - Zeitschrift für Säugetierkunde, 79 (4): 277282.

9. Djan, M., Popović, D., Veličković, N., Obreht, D., Vapa, L. (2013) Comparison of allozyme and microsatellite variability in brown hare populations (Lepus europaeus Pallas) from Vojvodina (Serbia), Biologia Serbica, 35, pp. 1-2. 
10. Djan, M., Stefanović, M., Veličković, N., Lavadinović, V., Alves, P.C., Suchentrunk, F. (2017) Brown hares (Lepus europaeus Pallas, 1778) from the Balkans: a refined phylogeographic model, Hystrix, the Italian Journal of Mammalogy, 28(2), pp. 1-8.

11. Djan, M., Veličković, N., Matić, I., Stefanović, M., Ćirović, D. (2018) Genetički monitoring vuka u Srbiji, In Drugi Kongres Biologa Srbije, Kladovo, 25-30. September, pp. 137.

12. Djan, M., Veličković, N., Obreht, D., Gagrcin, M., Beuković, M., Vapa, Lj. (2008) Microsatellite variability within captive wild boar population, In 7th International Symposium on Wild Boar (Sus scrofa) and on sub-order Suiformes (Ed, Nahlik, A.), University of West Hungary, 27-31 August 2008, pp. 77-77.

13. Djan, M., Veličković, N., Obreht, D., Kočiš, Tubić, N., Marković, V., Stevanović, M., Beuković, M. (2013) Mitochondrial DNA Control Region Variability in Wild Boars from West Balkans. Genetika 45 (2). pp. 515 - 526.

14. Djan, M., Veličković, N., Stefanović, M., Marković, V., Vidaković, D.O., Vapa, L. (2015) Genetic variation within and among brown hare (Lepus europaeus Pallas, 1778) populations in Serbia as inferred from microsatellites, Balkan Journal of Wildlife Research, 2(1), pp. 18-26.

15. De la Torre, A., Bosch, J., Iglesias, I., Muñoz, M., J., Mur, L., Martínez-López, B., SánchezVizcaíno, J., M. Assessing the risk of African swine fever introduction into the European Union by wild boar. Transboundary and Emerging Diseases. 2015; 62, pp. 272-9.

16. Djan, M. (2008) Polimorfnost mikrosatelita i mtDNK u populacijama zeca (Lepus europaeus), $\mathrm{PhD}$ Thesis, Faculty of Sciences, University of Novi Sad, Serbia.

17. Djan, M., Obreht, D., Vapa, L. (2006) Polymorphism of mtDNA regions in brown hare (Lepus europaeus) populations from Vojvodina (Serbia and Montenegro), European Journal of Wildlife Research, 52(4), pp. 288-291.

18. Djan, M., Veličković, N., Obreht, D., Stefanović, M., Beuković, D., Beuković, M. (2013) Brown hares in hunting areas of Vojvodina: genetic diversity as revealed by mtDNA sequences, In $2^{\text {nd }}$ International Symposium on Hunting „Modern aspects of sustainable management of game populations"', Novi Sad, Serbia, 17-20 October, pp.191-196.

19. Djan, M., Veličković, N., Popović, D., Obreht, D., Beuković, M., Vapa, L. (2012) Genetic monitoring of popular game species in hunting areas of Vojvodina [Serbia]. In International Symposium on Hunting Modern Aspects of Sustainable Management of Game Population, ZemunBelgrade (Serbia), 22-24 June 2012. Faculty of Agriculture, pp. 79-82.

20. Fickel, J., Schmidt, A., Putze, M., Spittler, H., Ludwig, A., Streich, J.W., Pitra, C. (2005) Genetic structure of populations of European brown hare: implications for management, Journal of Wildlife Management 69 (2), pp. 760-770.

21. Francisco, L., V., Langsten, A., A., Mellersh, C., S., Neal, C., L., Ostrander, E., A. (1996) A class of highly polymorphic tetranucleotide repeats for canine genetic mapping, Mammalian Genome, 7, pp. 359-362.

22. Frank, B., F., Monaco, A., Bath, A., J. (2015) Beyond standard wildlife management: a pathway to encompass human dimension findings in wild boar management, European Journal of Wildlife Research 61, pp. 723-730.

23. Fredholm, M., Wintero, A., K., Christensen, K., Kristensen, B., Nielsen, P., B., Davies, W., Archibald, A. (1993) Characterization of 24 porcine (dA-dC)n-(dT-dG)n microsatellites: genotyping of unrelated animals from four breeds and linkage studies, Mammalian Genome 4, pp. 187-192.

24. Gorše, I., Stefanović, M., Matić, I., Beuković, D., Popović, Z., Veličković, N., Đan, M. (2019) The genetic monitoring of brown hares (Lepus europaeus), In 6th Congress of the Serbian Genetic Society, Vrnjačka Banja (Serbia), 13-17 October 2019, pp. 161.

25. Hartl, G.B., Suchentrunk, F., Nadlinger, K., Willing, R. (1993) An integrative analysis of genetic differentiation in the brown hare Lepus europaeus based on morphology, allozymes, and mitochondrial DNA. Acta theriologica, 38, pp. 33-33.

26. Hewitt, G.M. (2000) The genetic legacy of the Quaternary ice ages, Nature, 405, pp. 907-913. 
27. Hindrikson, M., Remm, J., Pilot, M., Godinho, R., Stronen, A.V., Baltrunaite, L., Czarnomska, S.D., Leonard, J.A., Randi, E., Nowak, C., Akesson, M., Lopez-Bao, J.V., Alvares, F., Llaneza, L., Echegaray, J., Vilà, C., Ozolins, J., Rungis, D., Aspi, J., Paule, L., Skrbinsek, T., Saarma, U. (2016). Wolf population genetics in Europe: a systematic review, meta-analysis and suggestions for conservation and management. Biological reviews of the Cambridge Philosophical Society, 92(3), pp. 1601-1629.

28. Huang, M., E., Cadieu, E., Souciet, J., L., Galibert F. (1997) Disruption of six novel yeast genes reveals three genes essential for vegetative growth and one required for growth at low temperature, Yeast 13(12), pp. 1181-94.

29. Kaczensky P., Chapron G., Von Arx, M., Huber D., Andrén H., Linnell, J. (2013) Status, management and distribution of large carnivores - bear, lynx, wolf and wolverine - in Europe. Rome, Italy: Report prepared with the assistance of Istituto di Ecologia Applicata (Roma) and with the contribution of the IUCN/SSC Large Carnivore Initiative for Europe under contract $\mathrm{N}^{\circ}$ 070307/2012/629085/SER/B3 for the European Commission

30. Kasapidis, P., Suchentrunk, F., Magoulas, A., Kotoulas, G. (2005) The shaping of mitochondrial DNA phylogeographic patterns of the brown hare (Lepus europaeus) under the combined influence of Late Pleistocene climatic fluctuations and anthropogenic translocations, Molecular Phylogenetics and Evolution, 34(1), pp. 55-66.

31. Kryger, U., Robinson, T.J., Bloomer, P. (2002) Isolation and characterization of six polymorphic microsatellite loci in South African hares (Lepus saxatilis F. Cuvier, 1823 and Lepus capensis Linnaeus, 1758), Molecular Ecology Notes 2, pp. 422-424.

32. Lucchini, V., Galov, A., Randi, E. (2004) Evidence of genetic distinction and long-term population decline in wolves (Canis lupus) in the Italian Apennines, Molecular Ecology, 13: 523-536.

33. Mamuris, Z., Sfougaris, A. I., Stamatis, C. (2001) Genetic structure of Greek brown hare (Lepus europaeus) populations as revealed by mtDBNA RFLP-PCR analysis: implications for conserving genetic diversity, Biological Conservation, 101(2), pp. 187-196.

34. Martin, J., Kitchens, W.M., Hines, J.E. (2007) Importance of well-designed monitoring programs for the conservation of endangered species: case study of the snail kite, Conservation Biology, 21(2), pp. 472-481.

35. Matić I. (2017) Polimorfnost mikrosatelita u populaciji vuka (Canis lupus Linnaeus. 1758) Srbije, Master Thesis, Faculty of Sciences, University of Novi Sad, Serbia.

36. Matić, I., Stefanović, M., Gorše, I., Beuković, D., Popović, Z., Đan, M., Veličković, N. (2019) Brown hares in lowland hunting grounds of Serbia - microsatellites based genetic monitoring, In 34th IUGB Congress, Kaunas, Lithuania, 26-30 August 2019, pp.153.

37. Matić, I., Stefanović, M., Gorše, I., Veličković, N., Ćirović, D., Đan, M. (2019) Grey wolves in Serbia - genetic diversity as inferred from microsatellites, In 6th Congress of the Serbian Genetic Society, Vrnjačka Banja (Serbia), 13-17 October 2019, pp. 156.

38. Milenković, M., Jojić Šipetić, V., Blagojević, J., Tatović, S., Vujošević, M. (2010) Skull variation in Dinaric-Balkan and Carpathian gray wolf populations revealed by geometric morphometric approaches, Journal of Mammalogy., (2010) 91(2), pp. 376-386.

39. Milenković, M., Paunović, M., Cirović, D. (2007) Action plan for wolf Canis lupus L., 1758 conservation in Serbia. Phase I - strategic plan, Institute for Biological Research Siniša Stanković, Belgrade, Ministry of Environmental Protection Republic of Serbia, Project report.

40. Mougel, F., Mounolou, J.C., Monnerot, M. (1997) Nine polymorphic microsatellite loci in the rabbit, Oryctolagus cuniculus, Animal Genetics, 28, pp. 58-71.

41. Nichols, J.D., Williams, B.K. (2006) Monitoring for conservation, Trends in ecology \& evolution, 21(12), pp. 668-673.

42. Pritchard, J.K., Stephens, M. Donnelly, P. (2000) Inference of population structure using multilocus genotype data, Genetics, 155, pp. 945-959.

43. Randi, E. (2011) Genetics and conservation of wolves Canis lupus in Europe, Mammal Review, 41, pp. 99-111. 
44. Rohrer, G., A., Alexander, L., J., Keele, J., W., Smith, T., P., Beattie, C., W. (1994) A Microsatellite Linkage Map of the Porcine Genome, Genetics 136, pp. 231-245.

45. Scandura, M., Iacolina, L., Apollonio, M. (2011) Genetic diversity in the European wild boar Sus scrofa: phylogeography, population structure and wild $\mathrm{x}$ domestic hybridization, Mammalian Review, 41, pp. 125-137.

46. Schwartz, M.K., Luikart, G., Waples, R.S. (2007) Genetic monitoring as a promising tool for conservation and management, Trends in ecology \& evolution, 22(1), pp. 25-33.

47. Sez-Rozuela, C., and Tellera, J., L. (1986) The Increased Population of Wild Boar (Sus scrofa L.) in Europe, Mammalian Review, 16, pp. 97-101.

48. Smith, R.K., Vaughan Jennings, N., Harris, S. (2005) A quantitative analysis of the abundance and demography of European hares Lepus europaeus in relation to habitat type, intensity of agriculture and climate, Mammal review, 35(1), pp. 1-24.

49. Stamatis, C., Suchentrunk, F., Moutou, K., Giacometti, M., Haerer, G., Djan, M., Vapa, Lj., Vukovic, M., Tvrtković, N., Sert, H., Paulo, A., Mamuris, Z.. (2009) Phylogeography of the brown hare (Lepus europaeus) in Europe: a legacy of south-eastern Mediterranean refugia? Journal of Biogeography 36(3), pp. 515-528.

50. Stefanović, M., Veličković, N., Beuković, D., Beuković, M., Djan, M. (2018) Genetic diversity of brown hares (Lepus europaeus) from lowland hunting grounds in Serbia, Beiträge zur Jagd- und Wildforschung, 43, pp. 213-219.

51. Stefanović, M., Veličković, N., Beuković, D., Beuković, M., Djan, M., Suchentrunk, F. (2016) The impact of Landscape features on population genetic structure of European brown hares (Lepus europaeus Pallas, 1778) from Serbia, In 5th International Hunting and Game Management Symposium, Debrecen, Hungary, 10-12 November, pp. 22.

52. Suchentrunk, F., Mamuris, Z., Sfougaris, A., Stamatis, C. (2003) Biochemical genetic variability in brown hares (Lepus europaeus) from Greece, Biochemical Genetics, 41 (5/6), pp. 127-140.

53. Suchentrunk, F., Michailov, C., Markov, G., Haiden, A. (2000) Population genetics of Bulgarian brown hares Lepus europaeus: allozymic diversity at zoogeographical crossroads, Acta theriologica, 45(1), pp. 1-12.

54. Surridge, A.K., Bell, D.J., Rico, C., Hewitt, G.M. (1997) Polymorphic microsatellite loci in the European rabbit (Oryctolagus cuniculus) are also amplified in other lagomorph species, Animal Genetics, 28: pp. 302-305.

55. Šnjegota, D. (2018) Genetička struktura i filogeografski položaj populacije vuka (Canis lupus L. 1758) Bosne i Hercegovine, PhD Thesis, Faculty of Sciences, University of Novi Sad, Serbia.

56. Taberlet, P., Fumagalli, L., Wust-Saucy, A.-G., Cosson, J.F. (1998) Comparative phylogeography and postglacial colonization routes in Europe. Molecular Ecology, 7, pp. 453-464.

57. Vapa, Lj., Djan, M., Obreht, D., Hammer, S., Suchentrunk, F. (2007) Allozyme variability of brown hares (Lepus europaeus) from the Vojvodina (Serbia), compared to central and south eastern European populations, Acta Zoologica Academiae Scientiarum Hungaricae 53(1), pp. 75-87.

58. Vapa, Lj., Obreht, D., Vapa, M., Selmic, V. (2002) Genetic variability in brown hare (Lepus europeaus) populations in Yugoslavia, Zeitschrift für Jagdwissenschaft, 48(1), pp. 261-266.

59. Vapa, M., Selmić, V., Obreht, D., Vapa, Lj. (1999) Allozyme variability in natural populations of hares (Lepus europaeus, Pallas), Zbornik Matice srpske za prirodne nauke, 97, pp. 85-91.

60. Veličković, N. (2008) Varijabilnost mikrosatelita u populaciji divlje svinje (Sus scrofa) Master Thesis, Faculty of Sciences, University of Novi Sad, Serbia.

61. Veličković, N. (2014) Genetička analiza populacione strukture i filogeografija divlje svinje (Sus scrofa Linnaeus, 1758), PhD Thesis, Faculty of Sciences, University of Novi Sad, Serbia.

62. Veličković, N., Đan, M., Ferreira, E., Obreht, D., Beuković, M., Fonseca, C. (2013) Estimation of genetic variability of wild boar populations in Vojvodina based on microsatellites. Proceedings of the 2nd Intenational Symposium on hunting ' Modern aspects of sustainable management of game population", Novi Sad, Serbia, 17-20 October 2013: pp. 204-208. 
63. Veličković, N., Đan, M., Ferreira, E., Kočiš, Tubić, N., Obreht, D., Beuković, M., Fonseca, C. (2014) Comparative analysis of wild boar and domestic pig populations based on microsatellites data. Proceedings of the 3rd Intenational Symposium on Hunting "Moden aspects of sustainable management of game populations”, Beograd-Zemun, Srbija, 26 - 28 Sep 2014, pp. 139 - 143.

64. Veličković, N., Djan, M., Ferreira, E., Stefanović, M., Kočiš-Tubić, N., Fonseca, C. (2016) Genetic variability of wild boar populations in the northen Dinaric Balkans: how does it fit in European context? 11th Intenational Symposium on Wild boars and other Suids, Luxembourg, 5-8 Sept 2016, p. 50

65. Veličković N., Djan M., Ferreira E., Stergar M., Obreht D., Maletić V., Fonseca, C. (2015) From north to south and back: the role of the Balkans and other southern peninsulas in the recolonization of Europe by wild boar, Journal of Biogeography 42, pp. 716-728.

66. Veličković, N., Djan, M., Obreht, D., Gagrcin, M., Beuković, M., Vapa, Lj. (2008) Genetic variability within captive wild boar population from Danube region, $\mathrm{X}$ International Symposium "Young People and Multidisciplinary Research", Timisoara: Association for Multidisciplinary Research of West Zone of Romania, 13-14. November 2008. Proceedings 164-168.

67. Veličković, N., Djan M., Obreht D., Vapa Lj. (2012) Population genetic structure of wild boars in the West Balkan region. Russian Journal of Genetics 48, pp. 859-863.

68. Veličković, N., Djan, M., Zoric, M., Obreht, D., Gagrcin, M., Vapa, Lj. (2010) An assessment of the genetic diversity in the wild boar population from the Podunavlje-Podravlje hunting area, Archives of Biological Sciences, 62 (3), pp. 807-810.

69. Zachos, F.E., Ben Slimen, H., Hackländer, K., Giacometti, M., Suchentrunk, F. (2010) Regional genetic in situ differentiation despite phylogenetic heterogeneity in Alpine mountain hares, Journal of Zoology, 282, pp. 47-53.

Received: 06.12.2019.

Accepted: 30.03.2020.

Matić I., Gorše I., Stefanović M., Djan M., Veličković N. (2020): Review of genetic monitoring programs of wildlife species in Serbia, Balkan Journal of Wildlife Research, 5 (1), pp. 40-52. 